Article

\title{
Exposure to High-Intensity Light Systemically Induces Micro-Transcriptomic Changes in Arabidopsis thaliana Roots
}

\author{
Barczak-Brzyżek Anna ${ }^{1}$, Brzyżek Grzegorz ${ }^{2}$, Koter Marek ${ }^{1}\left(\mathbb{D}\right.$, Gawroński Piotr ${ }^{1, *}$ and \\ Filipecki Marcin 1,*(D) \\ 1 Department of Plant Genetics, Breeding and Biotechnology, Institute of Biology, \\ Warsaw University of Life Sciences-SGGW, 02-776 Warszawa, Poland; barczak.annak@gmail.com (B.-B.A.); \\ marek_koter@sggw.pl (K.M.) \\ 2 Institute of Biochemistry and Biophysics Polish Academy of Sciences, 02-106 Warszawa, Poland; \\ grzesiekbrzyzek@gmail.com \\ * Correspondence: piotr_gawronski@sggw.pl (G.P.); marcin_filipecki@sggw.pl (F.M.)
}

Received: 3 September 2019; Accepted: 15 October 2019; Published: 16 October 2019

check for updates

\begin{abstract}
In full sunlight, plants often experience a light intensity exceeding their photosynthetic capacity and causing the activation of a set of photoprotective mechanisms. Numerous reports have explained, on the molecular level, how plants cope with light stress locally in photosynthesizing leaves; however, the response of below-ground organs to above-ground perceived light stress is still largely unknown. Since small RNAs are potent integrators of multiple processes including stress responses, here, we focus on changes in the expression of root miRNAs upon high-intensity-light (HL) stress. To achieve this, we used Arabidopsis thaliana plants growing in hydroponic conditions. The expression of several genes that are known as markers of redox changes was examined over time, with the results showing that typical HL stress signals spread to the below-ground organs. Additionally, micro-transcriptomic analysis of systemically stressed roots revealed a relatively limited reaction, with only 17 up-regulated and five down-regulated miRNAs. The differential expression of candidates was confirmed by RT-qPCR. Interestingly, the detected differences in miRNA abundance disappeared when the roots were separated from the shoots before HL treatment. Thus, our results show that the light stress signal is induced in rosettes and travels through the plant to affect root miRNA levels. Although the mechanism of this regulation is unknown, the engagement of miRNA may create a regulatory platform orchestrating adaptive responses to various simultaneous stresses. Consequently, further research on systemically HL-regulated miRNAs and their respective targets has the potential to identify attractive sequences for engineering stress tolerance in plants.
\end{abstract}

Keywords: miRNA; high light; abiotic stress; systemic response; roots

\section{Introduction}

The simplistic model of plant roots taking up water and nutrients that are essential for plant growth and receiving from shoots sugars and auxins which drive root development is much more complicated than an availability-growth relationship. In recent years, knowledge about the role of roots as a component of the plant signaling network integrating environmental cues has greatly expanded, revealing roots' central role in optimizing plant nutrient demand in response to shoot-derived stress signals and changes in photosynthesis capacity [1,2]. The rate of carbon assimilation reflects the condition of the photosynthetic apparatus and depends on light availability, which varies according to season, diurnal rhythm, and canopy structure, in terms of both light intensity and spectrum. In terms of light intensity, two extreme situations can occur: (1) light deficiency and 
(2) excess light (EL) caused by high light intensity (HL). Because such HL incidents may lead to photoinhibition, photoprotective mechanisms are triggered to avoid or dissipate the excess of light energy. These mechanisms include ultrastructural adaptations (e.g., chloroplast movement and thylakoid proteins arrangement), physical energy dissipation (e.g., by heat and chlorophyll fluorescence), and a number of biochemical processes such as photochemical and non-photochemical quenching, chlororespiration, photorespiration, production of antioxidant enzymes (e.g., APX, SOD) as well as carotenoids, tocopherols, or small antioxidant molecules (e.g., ascorbate and glutathione) [3-8].

Given the substantial role of light in the regulation of plant developmental processes and stress response, it is not surprising that plants have an extremely sensitive light-sensing system, with photoreceptors dedicated to different wavelengths of light $[1,9]$. These photoreceptors include cryptochromes (CRYs) and phototropins (PHOT), which detect UV-A and blue light, phytochromes (PHYs), which detect red (R) and far-red (FR) light, and UV-B resistance locus 8 (UVR8), which detects UV-B light $[1,9,10]$. Since light may penetrate only several centimeters under the ground surface, for many years it was a puzzle how plant roots perceive light [9]. Although root anatomy, morphology, and physiology were observed to be regulated by light, the majority of the changes were attributed to changes in sugar availability due to fluctuations in light intensity and thus in photosynthesis. However, a growing body of evidence indicates that many aspects of these light systemic responses are part of a more complex signaling network. This was proven by studies that documented that photoreceptors occur all over the plant body, including in dark-grown roots. Additionally, in recent years, physical and genetic approaches have suggested that photoreceptors expressed in roots directly sense light [11,12]. For example in Arabidopsis thaliana plants, it was shown that a signal triggered by light was conducted through the stems to the roots, where photoactivated phytochrome B (phyB) triggered the expression of the transcription factor elongated hypocotyl 5 (HY5), and that there was a consequent accumulation of HY5 protein which resulted in the promotion of root growth in response to light $[11,12]$. Another breakthrough finding concerning light-regulated shoot-to-root signaling was presented by Chen et al. [13], who demonstrated that HY5 itself is a mobile signal which travels from rosettes to the underground part of $A$. thaliana plants. In the above-ground parts, HY5 underpins shoot growth with $\mathrm{C}$ assimilation, whereas in roots, it stimulates growth-enhancing $\mathrm{N}$ uptake by the up-regulation of NRT2.1, which encodes a major root $\mathrm{NO}_{3}{ }^{-}$transporter. These observations strongly support the idea that light is essential for the plant signaling network which modulates nutrient uptake and demand at the whole-plant level under different environmental conditions [14]. Such a long-distance signaling network is crucial for relaying information about the local environment and may involve different molecular components. One of the common components of such signaling, a possible stress integrator, is microRNA (miRNA). Its ability to travel through the plant has been well documented in the case of phosphate $(\mathrm{P})$ homeostasis regulation, where Arabidopsis miR399 appears to be an important regulator during P starvation [15-18]. Furthermore, miRNAs have been proven to play a role in many other nutrient-related responses [19-21] as well as in responses to other abiotic [22,23] and biotic stresses $[24,25]$. However, in most of these studies, long-distance miRNA transport was not proven. Systemic changes in miRNA expression in response to stress factors may engage other signaling molecules, such as mobile RNAs or peptides, molecules of a different nature, such as reactive oxygen species (ROS) or phytohormones, as well as calcium waves or electrical signaling [26-29].

Although miRNAs are major regulators of gene expression, their role in light stress signaling is not well understood, especially in the context of root response [30]. This is rather surprising, given that about $20 \%$ of genes in Arabidopsis are regarded as light-responsive [30-33]. Further expanding the knowledge about the role of miRNAs in HL-stressed plants is extremely interesting in the context of the recent study of Petrillo et al. [32]. They proved that splicing-one of the mechanisms by which gene expression is regulated by light-occurs not only in shoots but also in roots and observed changes that are regulated by redox signals derived from chloroplasts. Since splicing may influence miRNA expression, the question arises: Can HL stress directly or indirectly regulate the expression of root miRNAs, and what is the nature of the shoot-derived stress signal? To address this question, 
we analyzed HL-triggered changes in the expression of miRNAs in roots using a micro-transcriptomic approach followed by RT-qPCR analysis. Direct exposure of roots (separated from shoots before exposure to HL) to HL stress revealed that a stress signal is induced in rosettes and travels through the plant, thereby affecting the expression of miRNAs. The list of potential targets of HL-regulated root miRNAs opens interesting perspectives for engineering stress responses in plants.

\section{Results}

\subsection{HL-Induced Transcriptional Changes in A. thaliana Roots}

To study the HL response in A. thaliana roots, we used plants growing in a hydroponic system, which enables the continuous growth of roots in the dark and minimizes mechanical damage and stress. Plants growing in low-light conditions (LL; 100-120 $\mu \mathrm{mol}$ photons $\mathrm{m}^{-2} \mathrm{~s}^{-1}$ ) and a short-day photoperiod (Figure 1A) were subjected to two hours of HL stress at an intensity of $1500 \mu \mathrm{mol}$ photons $\mathrm{m}^{-2} \mathrm{~s}^{-1}$, and the expression of several HL-response-related genes was checked immediately following the stress and after $4 \mathrm{~h}$ of recovery, to confirm whether the stress signal spread to dark-grown roots.

HL response markers were selected on the basis of previous research which showed that an acclimation response was induced within minutes of episodes of HL in stressed tissues and was transmitted to HL-unexposed leaves of the same plant, thereby initiating an HL systemic acquired acclimation response (HL-SAA) [34,35]. HL-SAA is mainly regulated by retrograde signals derived from chloroplasts, such as changes in the plastoquinone (PQ) redox status pool, ROS production, or other retrograde signaling pathways [36-43]. The subsequent activation of photoprotective mechanisms is orchestrated by the transcriptional activation of many HL-, ROS-, hormone-, pathogenesis-, and drought-related genes [44-46].

In this study, we analyzed the root transcript level of two enzymes that are directly involved in ROS detoxification, namely, ascorbate peroxidase 2 (APX2 gene) and catalase 2 (CAT2 gene), as well as the transcript level of redox responsive transcription factor 1 (RRTF1 gene) and early light inducible protein 1 (ELIP1 gene), which have both been described as markers of HL-SAA [34,38]. Our analysis covered three consecutive time points: (1) before the HL stress (low-light control, LLc); (2) immediately after the HL stress episode (HLs); and (3) four hours of recovery in LL after HL stress (LLr) (Figure 1A,B). The transcript levels of APX2 and ELIP1 increased significantly within two hours of HL stress and decreased after the subsequent four hours of recovery. The transcript level of APX2 quickly reverted back to its LLc level after the HL episode; in contrast, after four hours of recovery, the transcript level of ELIP1 was still significantly up-regulated compared to the control. The transcript level of CAT2 decreased immediately after the HL episode, however, it returned to the control level after four hours in LL conditions. Meanwhile, the expression of RRTF1 decreased and remained low after four hours in low-light conditions (Figure 1B). These transcriptional changes in the expression of light-stress marker genes confirmed the induction of a stress response in roots kept in darkness. 
A
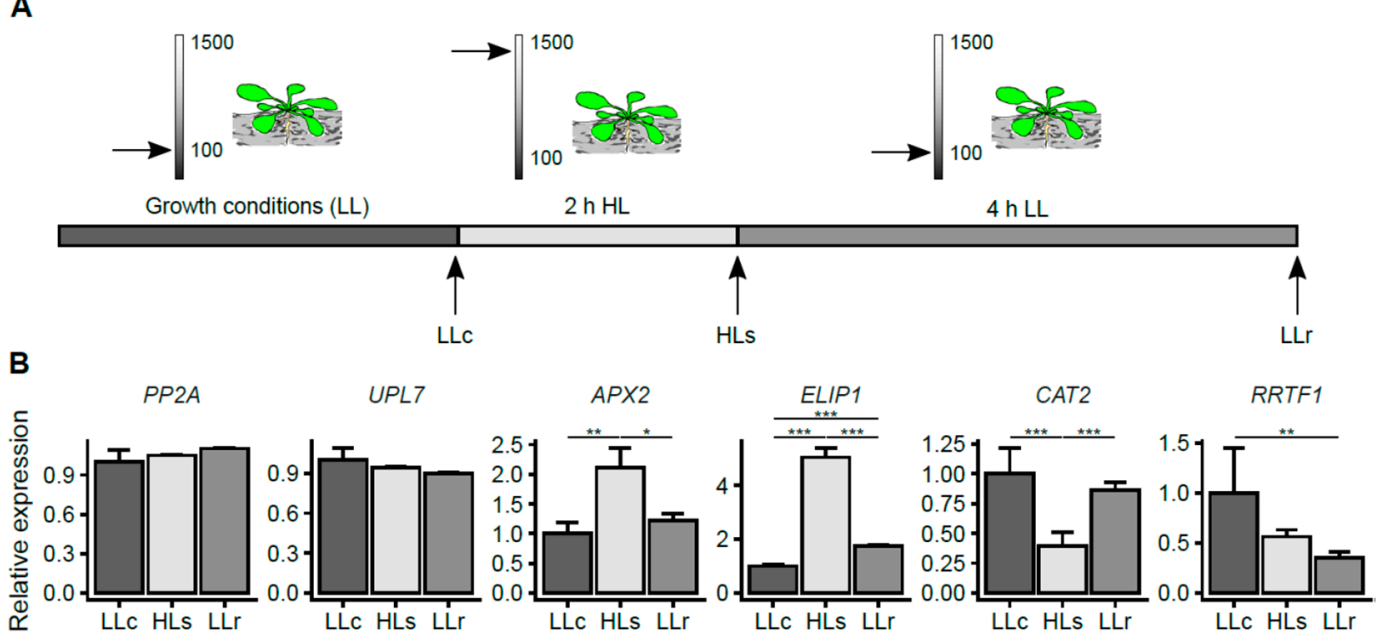

Figure 1. The transcriptional response of stress markers in Arabidopsis thaliana roots after the exposure of rosettes to high light intensity (HL). (A) Experimental scheme: LLc: roots of plants grown in low-light (LL) control conditions ( $2 \mathrm{~h}$ after the LL day started); HLs: roots of plants exposed to $2 \mathrm{~h}$ of HL stress; LLr: roots of plants exposed to $2 \mathrm{~h}$ of HL followed by $4 \mathrm{~h}$ of recovery in LL conditions. The arrows on the scales indicate the light intensity ( $\mu \mathrm{mol}$ photons $\mathrm{m}^{-2} \mathrm{~s}^{-1}$ ). (B) Relative expression of the marker genes compared to the genes PP2A and UPL7. Error bars represent the standard deviation, and asterisks represent significant differences at $p$-values $<0.05\left(^{*}\right),<0.01(* *)$, and $<0.001\left(^{* * *}\right)$. ANOVA and the HSD Tukey test were applied for statistical analysis. Results from two independent experiments were each pooled from six plants and three technical replicates.

\subsection{HL-Triggered Systemic Changes in the Expression of miRNAs}

After verifying that the stress signal was transferred from shoots to dark-grown roots and resulted in changes in the expression of HL marker genes, we performed micro-transcriptomic analysis (see Supplementary Table S1). The obtained data were filtered using the cutoff fold change (FC) $\leq 0.65$ and $F C \geq 1.5$, which allowed us to select a relatively limited set of 17 up-regulated and 5 down-regulated miRNAs (Figure 2A,B; Supplementary Table S1). Among the up-regulated miRNAs, the expression activation of five miRNAs was restricted to one time point, while the expression activation of seven miRNAs was induced in both treatments (immediately after the HL stress and after four hours of recovery, respectively). Of the five miRNAs whose expression was down-regulated in response to the HL episode, four were commonly down-regulated in the HLs and LLr conditions, and one was down-regulated exclusively in the LLr condition. No miRNAs were down-regulated only in the HLs condition. The micro-transcriptomic screening was further validated using two RT-qPCR methods. The first one, which was performed according to Androvic et al. [47], used two-tailed RT target-specific primers consisting of two hemiprobes, whereas the second one was based on a universal RT reaction (for details, see the Materials and Methods section and Supplementary Table S2). We observed statistically significant changes in the micro-transcriptomic data for three up-regulated miRNAs (miR160b, miR394a, and miR8175) and one down-regulated miRNA (miR169f). Changes were also observed in the induction of miR157a, however, they were not statistically significant (Figure 2C). 
A

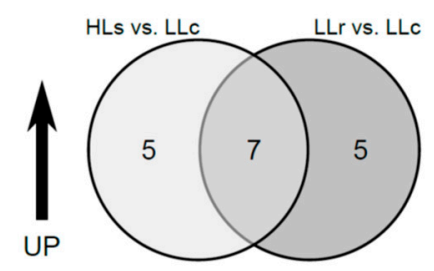

B

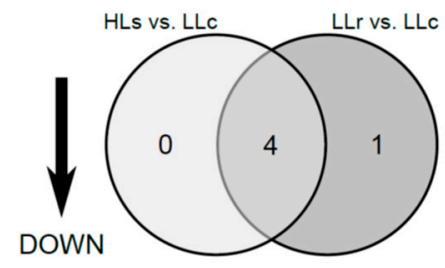

C
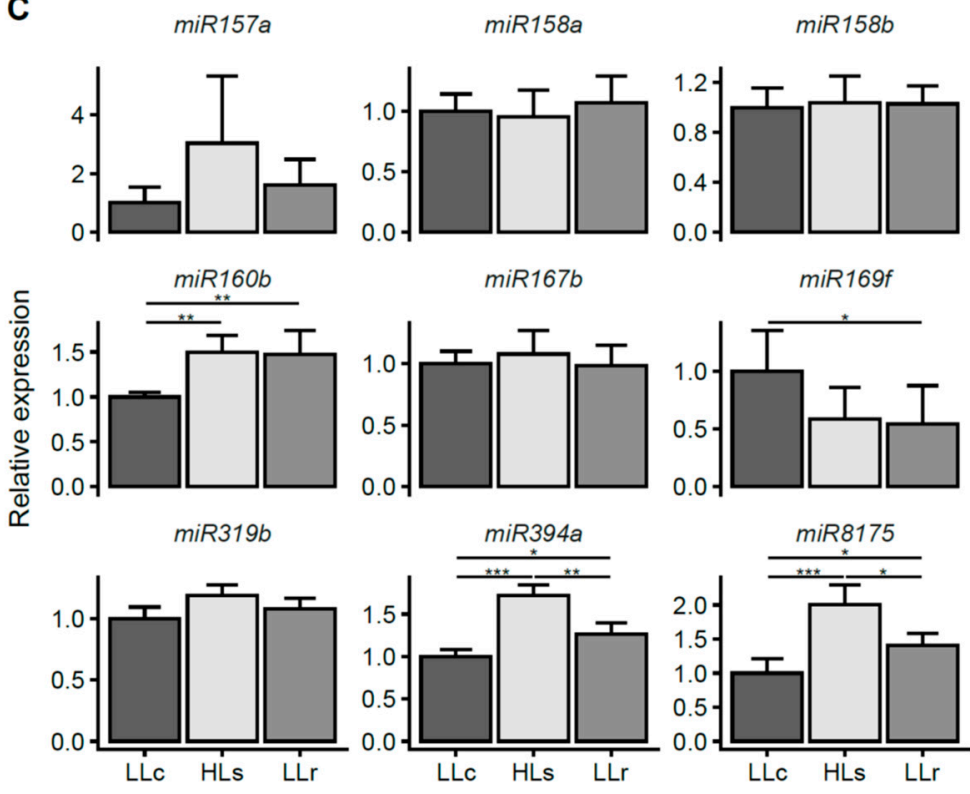

Figure 2. Micro-transcriptomic changes in A. thaliana roots induced by HL treatment of rosettes (A) Venn diagram representing the number of miRNAs that were up-regulated after HL treatment compared to control roots. (B) Venn diagram representing the number of miRNAs that were down-regulated after HL treatment compared to control roots. (C) Validation of selected micro-transcriptomic changes in miRNA expression, relative to the expression of two references, snoRNA85 and snoRNA101, using the RT-qPCR method. Error bars represent the standard deviation, and asterisks represent significant differences at $p$-values $<0.05\left({ }^{*}\right),<0.01(* *)$, and $<0.001(* *)$. ANOVA and the HSD Tukey test were applied for statistical analysis. Results are from three independent experiments each pooled from six plants and three technical replicates.

\subsection{Stress Signal is Induced in Rosettes}

Next, we investigated whether the light stress signal which caused the changes in miRNA expression in roots could originate from rosettes only or whether it could also be generated in HL-exposed roots. To test this, the roots were separated from the shoots and subsequently exposed to $2 \mathrm{~h}$ of HL (Figure 3A). Additionally, taking into consideration the possible effect of wounding on the level of expression of miRNA, roots dissected from shoots that were kept in darkness were also included in the analysis (OFF; see Figure 3A). For all HL stress-regulated miRNAs, we were unable to induce similar local changes in HL-exposed roots (Figure 3B). Only in the case of miR169f, we observed a slight HL induction which was opposite to the effect observed in the shoot-root experiment and similar to the trend of the wounding reaction (Figure 3B). Interestingly, in two cases, namely, miR157a and miR8175, the local HL stress seemed to abolish the slight effect of mechanical root detachment. The above data suggest that the main light stress signals were generated in rosettes. 
A

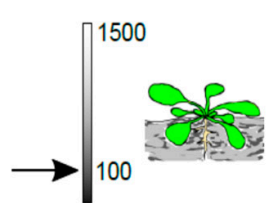

LLC

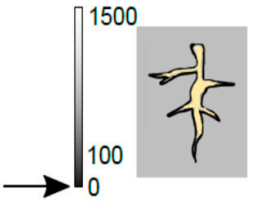

OFF

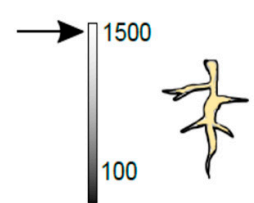

HLS

B
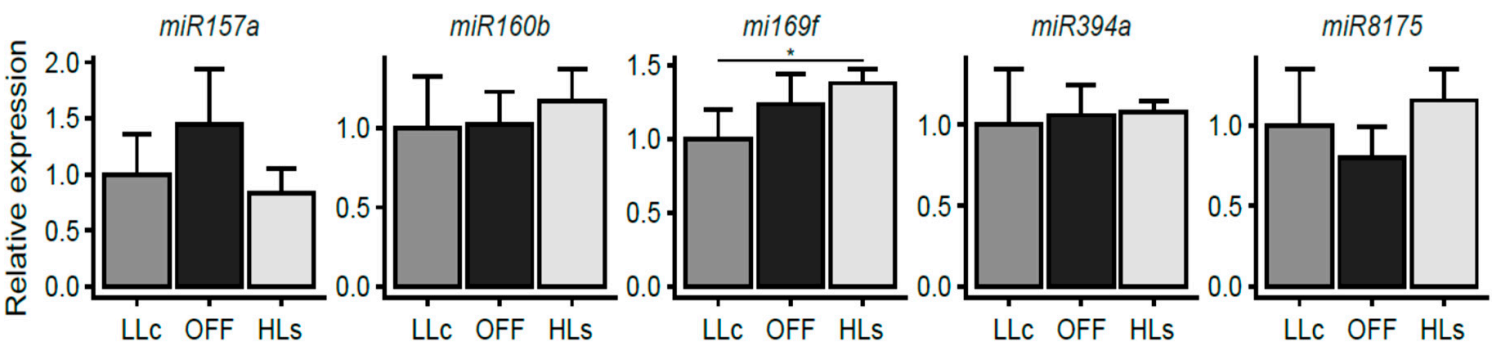

Figure 3. Verification of the stress signal source. (A) Experimental scheme: LLc: control roots (collected from plants grown in LL for $2 \mathrm{~h}$ ); OFF: roots dissected from shoots as in LLc and kept in the dark for 2 h; HLs: roots dissected from shoots as in LLc and exposed to HL for $2 \mathrm{~h}$. The arrows on the scales indicate light intensity ( $\mu \mathrm{mol}$ photons $\mathrm{m}^{-2} \mathrm{~s}^{-1}$ ). (B) Expression level of miRNAs relative to two references, snoRNA85 and snoRNA101. Error bars represent the standard deviation, and asterisks represent significant differences at $p$-values $<0.05\left(^{*}\right)$. ANOVA and the HSD Tukey test were applied for statistical analysis. Results are from three independent experiments each pooled from six plants and three technical replicates.

\subsection{Prediction of Potential Targets}

Since the miRNAs are able to specifically suppress individual protein-coding genes, the identification of mRNA targets is the first and most important step in interpreting miRNAs engagement in plant growth, development, or stress response. Therefore, we used the psRNATarget software to predict potential targets for the differentially expressed miRNAs (Table 1, Supplementary Table S3) [48].

Table 1. Most significant hits from the prediction of mRNA targets for confirmed miRNAs, obtained using the psRNATarget software. More potential targets and search parameters are presented in Supplementary Table S3.

\begin{tabular}{|c|c|c|c|c|}
\hline miRNA & Target ID & Target Name & Target Function & References \\
\hline \multirow{3}{*}{ ath-miR160b } & AT2G28350.1 & ARF10 & \multirow{3}{*}{ Response to auxin signaling } & \multirow{3}{*}[49,50]{} \\
\hline & AT4G30080.1 & ARF16 & & \\
\hline & AT1G77850.1 & ARF17 & & \\
\hline ath-miR169f-3p & AT3G59770.1 & SAC9 & Probable phosphoinositide phosphatase & [51] \\
\hline ath-miR394a & AT5G36170.2 & HCF109 & $\begin{array}{l}\text { Proper translation, stability and processing } \\
\text { of polycistronic transcripts in chloroplasts }\end{array}$ & [52] \\
\hline ath-miR8175 & AT2G36250.2 & FtsZ2-1 & Required for plastid division & [53] \\
\hline
\end{tabular}

ARF: Auxin Response Factor. SAC9: Probable phosphoinositide phosphatase. HCF: High chlorophyll fluorescent.

Only one candidate, miR160b, targets transcription factors, namely, auxin response factors (ARFs), which have been previously proven to be regulated by miRNA. Another one, miR169f-3p, targets an important enzyme in phosphoinositide signaling. Interestingly, two other miRNAs, miR394a 
and miR8175, may target transcripts of nuclear-encoded, important players in chloroplast biogenesis and functioning. These are promising candidates for future research, which should be extensively functionally analyzed.

\section{Discussion}

Above-ground and underground parts of plants play different roles, which must be synchronized to ensure optimal growth and development under various environmental cues [10]. Since light is both extremely variable and the most powerful factor which influences plant performance, plants should possess robust and precise molecular regulatory mechanisms that are deeply integrated into any physiological process. Indeed, light plays its role not only by regulating photosynthesis but also by possibly cross-talking with nutrient acquisition and the regulation of the stress response both locally and systemically $[14,35,54]$.

In this study, we analyzed the high-light stress response of $A$. thaliana roots grown in darkness. The root response was confirmed by monitoring the transcripts typically induced in shoots upon oxidative stress: APX2 and CAT2. APX2 reacted by a strong induction and recovered to its initial level after $4 \mathrm{~h}$, which is in accordance with its role in systemic acclimation to stress [34]. The CAT2 transcript was down-regulated just after the HL treatment but also recovered within $4 \mathrm{~h}$ of LL. This reaction is different from the induction observed in rosette leaves, indicating that oxidative stress signal transduction reaches the roots but is not related to elevated levels of $\mathrm{H}_{2} \mathrm{O}_{2}$ [55]. The observed RRTF1 gene expression supports this notion, showing transcriptional down-regulation in the roots immediately after HL and maintaining a low level even $4 \mathrm{~h}$ after stress exposure. This is in line with earlier reports by Matsuo et al. [56]. ELIP1 is a nuclear-encoded, chlorophyll ab-binding-related protein, localized in the chloroplast thylakoid membranes, which is differentially transcribed in response to light stress in the leaves, with a possible photoprotective role, preventing photo-oxidation or dissipating excess energy [57]. Its role, however, can be wider including its participation in the phytochrome signaling pathway leading to seed germination in tomato and Arabidopsis [58,59]. In this report, we observed a strong ELIP1 induction in shaded roots of Arabidopsis plants treated with HL, indicating that similarly to other above-described genes, there are stress signals generated in the shoots that move to the underground plant parts. This observation leads also to the question of what the ELIP1 role could be in roots that do not contain chlorophyll and have a number of plastids much lower than in leaf mesophyll. Despite the fact that this is a fascinating question, in the present report, we will focus on regulatory mechanisms evoked by aboveground HL episodes influencing shaded root functioning.

An interesting mediator of such information exchange is miRNA, which is a sequence-specific and potent post-transcriptional, negative regulator of gene expression. Several reports have described the complexity of how light influences miRNA expression following a variety of light treatments $[30,31,60]$. Despite the crucial role of roots in the optimization of plant growth by the spatial and temporal adjustment of nutrient demand to photosynthetic capacity under various environmental constraints, their significance is often overlooked.

Using micro-transcriptomic analysis, we were able to select candidates for subsequent validation by RT-qPCR methods, which confirmed the significant up-regulation of miR160b, miR394a, and miR8175, while down-regulation was shown only for miR169f. Since previous reports described that alternative splicing (AS) is regulated by light in both shoots and roots and proved that the observed changes in splice variants proportions diminished when roots were dissected from rosettes before exposition to light [32], our further study was directed towards checking if the same is true for the regulation of miRNA expression. By exposing dissected roots to HL, we proved our assumption that the stress signal was generated in rosettes. Although the effect of light on AS required functional chloroplasts and was initiated by changes in the $\mathrm{PQ}$ redox status, the nature of the signaling molecules that travel through plants is still unknown [32]. Moreover, there may be crosstalk between AS and miRNA-mediated post-transcriptional gene regulation, which makes the study of the effects of light on these two important gene regulatory mechanisms extremely interesting [61]. For example, in Physcomitrella patens, 
it was shown that most of the factors involved in miRNA processing undergo AS [61,62]. Additionally, it was recently found that light may regulate miRNA processing by changing the phosphorylation state of hyponastic leaves 1 (HYL1), an important player in miRNA maturation. An extended period of light deprivation led to the degradation of HYL1, while the restoration of light resulted in the dephosphorylation of HYL1 protein and switched on miRNA biogenesis [63]. Since light may regulate many steps of miRNA biogenesis, including transcription, splicing, stabilization, and degradation, much more work should be performed to explore these areas of plant biology [64].

An obvious complement to the research on pathways involving miRNAs is the identification of their targets. Such work could open the way to the application of genetic engineering to change agronomic traits. One example in which such a strategy was successfully applied is the manipulation of chloroplastic superoxide dismutase (CSD2) as a target of miR398, which improved plant tolerance to $\mathrm{HL}$, heavy metals, and other oxidative stresses [65].

Among miRNAs in HL-regulated Arabidopsis root, ath-miR160b is known to regulate the ARF family genes $A R F 10, A R F 16$, and $A R F 17$. ARF10 and ARF16, although functionally redundant, have been shown to be involved in the determination of Arabidopsis root architecture. The miR160-dependent down-regulation of $A R F 10$ and ARF16 led to a reduction in main-root gravitropism and main-root length and to an increase in the number of lateral roots [66]. ARF17 has been shown to be a negative regulator of acyl-acid-amido synthetases (GH3s) involved in the formation of inactive jasmonic acid (JA) conjugates, leading to a low level of active JA-Ile, which negatively modulates the adventitious rooting process through the activation of the COI1 signaling pathway [67]. Thus, the observed up-regulation of miR160 may generate a signal for root system expansion via the inhibition of all potential ARF targets. Moreover, the specificity of JA-Ile partially overlaps with that of JA, a hormone involved in herbivore resistance; however, due to the lower activity of JA-Ile and the availability of mainly shoot-derived data [68], the possible role of miR160 in managing trade-offs between stress tolerance and growth and reproduction is unclear and requires more research.

The miRNA miR169f-3p is the only confirmed candidate which was significantly down-regulated in roots upon HL stress and remained suppressed after four hours of recovery in low light conditions. Its most significant putative target is a probable phosphoinositide phosphatase, SAC9, which may terminate stress-induced signaling via phosphoinositides (PIs), signaling molecules that regulate cellular events including vesicle targeting and interactions between membrane and cytoskeleton. The sac 9 mutant of Arabidopsis accumulates elevated levels of phosphoinositides and produces characteristics of a constitutive stress response, including dwarfism, closed stomata, and anthocyanin accumulation. Moreover, the sac 9 mutant overexpresses stress-induced genes and over-accumulates reactive oxygen species [51]. Since miR169f-3p down-regulation should enhance SAC9 expression and consequently should have an adverse effect, this might suggest that it plays a different role in roots.

In the case of two other miRNA targets, research suggests their possible role in regulating nuclear genes coding for proteins involved in basic processes in chloroplasts, namely, translation (miR394a/HCF109 [52]) and plastid division (miR8175/FtsZ2-1 [53]). We speculate that plastids, besides the relatively low abundance in root cells, may nevertheless function there as specific stress hubs [69,70], which can explain the existence of systemically induced and miRNA-dependent regulatory modules. Engagement of Arabidopsis root leucoplasts by the stress response was also postulated by Itoh and Fujiwara [71]. Alternatively, the observed miRNA dynamics might be a residual effect of processes observed in the above-ground parts of the plant, suggesting an interesting involvement of miRNA in retrograde regulation [72] as well as miRNA shoot-to-root movement [73].

The present study contributes to the understanding of plant function in changeable environments regarding the potential of the miRNA-mediated machinery in shoot-to-root communication. The results of this study should be useful for the development of stress-tolerant crops, but first, many hypotheses have to be verified experimentally. 


\section{Material and Methods}

\subsection{Plant Material and Growing Conditions}

The A. thaliana plants used in this study were a Col-0 ecotype (Nottingham Arabidopsis Stock Centre ID 76778). Seeds were surface-sterilized using the chlorine gas method according to Lindsey et al. [74]. Seeds were put in PCR tubes placed in a plastic rack in a desiccator and then exposed to approximately $6 \% \mathrm{Cl}_{2}$ for $3 \mathrm{~h}$. Next, the tubes were placed in laminar flow hood to eliminate the chlorine gas and then sowed and kept for two days at $4{ }^{\circ} \mathrm{C}$ to synchronize germination. Before analyses, the $A$. thaliana plants were grown in hydroponic conditions for 4 weeks, on the basis of Conn et al. method [75]. Briefly, sterilized seeds were placed in black Eppendorf tubes filled by half-strength Murashige and Skoog medium in a plastic opaque container with basal nutrient solution (for details see [73]) which was changed once a week in the first 3 weeks and then twice during the fourth week. During the whole experiment, the roots were protected from light. Controlled growth conditions were set to short day $\left(8 \mathrm{~h} \mathrm{light} / 16 \mathrm{~h}\right.$ dark; $22^{\circ} \mathrm{C} / 20^{\circ} \mathrm{C}$ ), $70 \%$ air humidity, and low light intensity (LL; 100-120 $\mu \mathrm{mol}$ photons $\mathrm{m}^{-2} \mathrm{~s}^{-1}$ ).

\subsection{High-Light Treatment}

HL treatments were performed by the exposure of LL-adapted plants ( $2 \mathrm{~h}$ after the day started) to HL stress for $2 \mathrm{~h}$ using LED light sources with a light intensity of $1500 \mu \mathrm{mol}$ photons $\mathrm{m}^{-2} \mathrm{~s}^{-1}$ (Photon Systems Instruments, Brno, Czech Republic).

\subsection{Root Separation}

The roots of plants growing hydroponically in LL conditions ( $2 \mathrm{~h}$ after the day started) were separated from the shoots using a scalpel and then put into Petri dishes (150 $\mathrm{mm}$ diameter) with three layers of laboratory filter paper soaked with Basal Nutrient Solution (medium composition according to [75]). The Petri dishes were kept in the dark (OFF) or exposed to HL for $2 \mathrm{~h}$ (HLs).

\subsection{RNA Isolation}

RNA extraction was performed using a Universal RNA/miRNA purification kit (EURX, Gdańsk, Poland) according to the manufacturer's instructions. RNA was eluted using $50 \mu \mathrm{L}$ of RNAse-free water. The RNA concentration was estimated using NanoDrop 1000 (Thermo Fisher Scientific, Wilmington, MA, USA), and RNA integrity was confirmed using an Experion Automated Electrophoresis System (Bio-Rad, Hercules, CA, USA). In all cases, one biological replicate was pooled from six independent plants.

\subsection{Preparation of Libraries and Micro-Transcriptomic Analysis}

The preparation of miRNA libraries was outsourced to Genomed S.A. (Warsaw, Poland). Briefly, libraries were prepared using the NEBNext@Small RNA Library Prep Set for Illumina@(Multiplex Compatible). Sequencing was performed using the Illumina HiSeq 4000 platform (Illumina Inc., San Diego, CA, USA). The results were analyzed according to the pipeline in Supplementary Figure S1.

\subsection{Expression of Marker Genes Determined by RT-qPCR}

\subsection{1. cDNA Synthesis}

Reverse transcription was performed using a Quantitect Reverse Transcription kit (Qiagen, Hindel, Germany) according to the manufacturer's instructions. cDNA was synthesized from $1 \mu \mathrm{g}$ of total RNA. 


\subsubsection{Quantitative PCR}

Quantitative RT-PCR was performed in triplicate using a Bio-Rad CFX96 Touch TM Real-Time PCR Detection System (Bio-Rad, Hercules, CA, USA) with the primers listed in Supplementary Table S2. Real-time PCR cycling conditions were optimized depending on the primer used in the protocol, and relative expression was calculated relative to the UPL7 (AT3G53090) and PP2A (AT1G13320) genes. Product melting curves were generated following PCR to ensure the purity of the amplification products.

\subsection{Detection of Mature miRNAs Using Two-Tailed qPCR}

\subsection{1. cDNA Synthesis}

Reverse transcription for miRNAs was performed with a qScript flex cDNA synthesis kit (Quantabio, Beverly, MA, USA) according to Androvic et al. [47] in the total reaction volume of $10 \mu \mathrm{L}$. RNA was diluted in TE-LPA buffer (TE buffer with linear polyacrylamide at a final working concentration of $20 \mu \mathrm{g} / \mathrm{mL}$ ). The RT reaction mixture contained $10 \mathrm{ng}$ of total RNA, $1 \times$ RT buffer, $0.05 \mu \mathrm{M}$ RT primer, $1 \mu \mathrm{L}$ GSP enhancer, and $0.5 \mu \mathrm{L}$ RT enzyme. RT reactions were incubated in PCR tubes for $45 \mathrm{~min}$ at $25^{\circ} \mathrm{C}$ and for $5 \mathrm{~min}$ at $85^{\circ} \mathrm{C}$ and then held at $4{ }^{\circ} \mathrm{C}$.

\subsubsection{Quantitative PCR}

qPCR was performed according to Androvic et al. [47] in a total reaction volume of $10 \mu \mathrm{L}$ containing $1 \times$ SYBR (BiochemDevelopment, Gdańsk, Poland), $0.4 \mu \mathrm{M}$ forward and reverse primers, and $0.4 \mathrm{ng}$ of cDNA diluted product. The reactions were performed in triplicates and incubated in a CFX 96 Real-Time Detection System (96 well plates; Bio-Rad, Hercules, CA, USA) at $95^{\circ} \mathrm{C}$ for $30 \mathrm{~s}$, followed by 45 cycles of $5 \mathrm{~s}$ at $95^{\circ} \mathrm{C}$ and $15 \mathrm{~s}$ at $60^{\circ} \mathrm{C}$. Reaction specificity was assessed by melting curve. The relative expression level was calculated relative to snoRNA85 (NCBI Accession Number AJ505658) and snoRNA101 (NCBI Accession Number AJ505631).

\subsection{Detection of Mature miRNA Using Mir-X miRNA}

\subsection{1. cDNA Synthesis}

Reverse transcription was performed using $300 \mathrm{ng}$ RNA and a Mir-X miRNA First-Strand Synthesis Kit (Takara Bio Inc., Kusatsu, Japan). The total volume of the reaction mixture was $10 \mu \mathrm{L}$. The reverse transcription was performed at $37^{\circ} \mathrm{C}$ for $1 \mathrm{~h}$ followed by enzyme inactivation at $85^{\circ} \mathrm{C}$ for $5 \mathrm{~min}$.

\subsubsection{Quantitative PCR}

qPCR was performed in a total reaction volume of $20 \mu \mathrm{L}$ containing $10 \mu \mathrm{L}$ SYBR (BiochemDevelopment, Gdańsk, Poland), $4 \mu \mathrm{L}$ cDNA diluted product $\left(1 \mathrm{ng} \mu \mathrm{L}^{-1}\right)$, and two mixed template-specific primers $(10 \mu \mathrm{M})$ designed using the miRPrimer software (see Supplementary Table S1). The reactions were performed in triplicates and incubated in a CFX 96 Real-Time Detection System (96 well plates; Bio-Rad, Hercules, CA, USA). Reaction specificity was assessed by melting curve. The relative expression level was calculated relative to snoRNA85 (NCBI Accession Number AJ505658) and snoRNA101 (NCBI Accession Number AJ505631).

\subsection{Target Transcript Prediction}

Target transcripts for the presented miRNAs were predicted using the psRNATarget Database [48]. Search parameters were set to default, except the maximum expectation, which was set to 2.5 , and the length for complementarity scoring, which was 19 . The $A$. thaliana unigene DFCI Gene Index (AGI; version 15, released on 2010_04_08) library was used. 


\subsection{Statistical Analysis}

Statistical analysis was performed with the R software v.2.13.

Supplementary Materials: Supplementary materials can be found at http://www.mdpi.com/1422-0067/20/20/5131/s1.

Author Contributions: Conceptualization: B.-B.A., F.M., and G.P.; Data curation, F.M.; Funding acquisition, B.-B.A. and F.M.; Investigation, B.-B.A., B.G., K.M.; Methodology, B.-B.A., B.G., K.M.; Project administration, B.-B.A., F.M.; Supervision, F.M., and G.P.; Visualization, G.P.; Writing—original draft, B.-B.A. and F.M.; Writing一review and editing, B.-B.A. and F.M.

Funding: This study was supported by funding from the Polish National Science Center, project numbers 2016/23/N/NZ3/02237 and 2017/25/B/NZ9/02574.

Conflicts of Interest: The authors declare no conflict of interest.

\section{References}

1. Van Gelderen, K.; Kang, C.; Pierik, R. Light Signaling, Root Development, and Plasticity. Plant Physiol. 2018, 176, 1049-1060. [CrossRef]

2. Ruffel, S.; Gojon, A. Systemic nutrient signalling: On the road for nitrate. Nat. Plants 2017, 3, 17040. [CrossRef]

3. Foyer, C.H.; Noctor, G. Oxidant and antioxidant signalling in plants: A re-evaluation of the concept of oxidative stress in a physiological context. Plant Cell Environ. 2005, 28, 1056-1071. [CrossRef]

4. Foyer, C.H.; Noctor, G. Redox regulation in photosynthetic organisms: Signaling, acclimation, and practical implications. Antioxid. Redox Signal. 2009, 11, 861-905. [CrossRef]

5. Foyer, C.H.; Shigeoka, S. Understanding Oxidative Stress and Antioxidant Functions to Enhance Photosynthesis. Plant Physiol. 2011, 155, 93-100. [CrossRef]

6. Fryer, M.J. The antioxidant effects of thylakoid Vitamin E ( $\alpha$-tocopherol). Plant Cell Environ. 1992, 15, 381-392. [CrossRef]

7. Murchie, E.H.; Niyogi, K.K. Manipulation of Photoprotection to Improve Plant Photosynthesis. Plant Physiol. 2011, 155, 86-92. [CrossRef]

8. Ware, M.A.; Belgio, E.; Ruban, A.V. Comparison of the protective effectiveness of NPQ in Arabidopsis plants deficient in PsbS protein and zeaxanthin. J. Exp. Bot. 2015, 66, 1259-1270. [CrossRef]

9. Mo, M.; Yokawa, K.; Wan, Y.; Baluška, F. How and why do root apices sense light under the soil surface? Front. Plant Sci. 2015, 6, 775. [CrossRef]

10. Sakuraba, Y.; Yanagisawa, S. Light signalling-induced regulation of nutrient acquisition and utilisation in plants. Semin. Cell Dev. Biol. 2018, 83, 123-132. [CrossRef]

11. Lee, H.-J.; Ha, J.-H.; Kim, S.-G.; Choi, H.-K.; Kim, Z.H.; Han, Y.-J.; Kim, J.-I.; Oh, Y.; Fragoso, V.; Shin, K.; et al. Stem-piped light activates phytochrome B to trigger light responses in Arabidopsis thaliana roots. Sci. Signal. 2016, 9, ra106. [CrossRef] [PubMed]

12. Lee,H.-J.; Ha, J.-H.; Park, C.-M. Underground roots monitor aboveground environment by sensing stem-piped light. Commun. Integr. Biol. 2016, 9, e1261769. [CrossRef] [PubMed]

13. Chen, X.; Yao, Q.; Gao, X.; Jiang, C.; Harberd, N.P.; Fu, X. Shoot-to-Root Mobile Transcription Factor HY5 Coordinates Plant Carbon and Nitrogen Acquisition. Curr. Biol. 2016, 26, 640-646. [CrossRef] [PubMed]

14. Ruffel, S. Nutrient-related Long-Distance Signals: Common players and possible crosstalk. Plant Cell Physiol. 2018. [CrossRef]

15. Aung, K.; Lin, S.-I.; Wu, C.-C.; Huang, Y.-T.; Su, C.-L.; Chiou, T.-J. pho2, a phosphate overaccumulator, is caused by a nonsense mutation in a microRNA399 target gene. Plant Physiol. 2006, 141, 1000-1011. [CrossRef]

16. Bari, R.; Pant, B.D.; Stitt, M.; Scheible, W.-R. PHO2, MicroRNA399, and PHR1 Define a Phosphate-Signaling Pathway in Plants. Plant Physiol. 2006, 141, 988-999. [CrossRef]

17. Chiou, T.-J.; Aung, K.; Lin, S.-I.; Wu, C.-C.; Chiang, S.-F.; Su, C.-L. Regulation of phosphate homeostasis by MicroRNA in Arabidopsis. Plant Cell 2006, 18, 412-421. [CrossRef]

18. Fujii, H.; Chiou, T.-J.; Lin, S.-I.; Aung, K.; Zhu, J.-K. A miRNA involved in phosphate-starvation response in Arabidopsis. Curr. Biol. 2005, 15, 2038-2043. [CrossRef]

19. Abdel-Ghany, S.E.; Pilon, M. MicroRNA-mediated systemic down-regulation of copper protein expression in response to low copper availability in Arabidopsis. J. Biol. Chem. 2008, 283, 15932-15945. [CrossRef] 
20. Kawashima, C.G.; Yoshimoto, N.; Maruyama-Nakashita, A.; Tsuchiya, Y.N.; Saito, K.; Takahashi, H.; Dalmay, T. Sulphur starvation induces the expression of microRNA-395 and one of its target genes but in different cell types. Plant J. Cell Mol. Biol. 2009, 57, 313-321. [CrossRef]

21. Liang, G.; He, H.; Yu, D. Identification of Nitrogen Starvation-Responsive MicroRNAs in Arabidopsis thaliana. PLoS ONE 2012, 7, e48951. [CrossRef]

22. Barciszewska-Pacak, M.; Milanowska, K.; Knop, K.; Bielewicz, D.; Nuc, P.; Plewka, P.; Pacak, A.M.; Vazquez, F.; Karlowski, W.; Jarmolowski, A.; et al. Arabidopsis microRNA expression regulation in a wide range of abiotic stress responses. Front. Plant Sci. 2015, 6, 410. [CrossRef]

23. Zhang, B. MicroRNA: A new target for improving plant tolerance to abiotic stress. J. Exp. Bot. 2015, 66, 1749-1761. [CrossRef]

24. Brant, E.J.; Budak, H. Plant Small Non-coding RNAs and Their Roles in Biotic Stresses. Front. Plant Sci. 2018, 9, 1038. [CrossRef]

25. Islam, W.; Qasim, M.; Noman, A.; Adnan, M.; Tayyab, M.; Farooq, T.H.; Wei, H.; Wang, L. Plant microRNAs: Front line players against invading pathogens. Microb. Pathog. 2018, 118, 9-17. [CrossRef]

26. Chien, P.-S.; Chiang, C.-B.; Wang, Z.; Chiou, T.-J. MicroRNA-mediated signaling and regulation of nutrient transport and utilization. Curr. Opin. Plant Biol. 2017, 39, 73-79. [CrossRef]

27. Gilroy, S.; Białasek, M.; Suzuki, N.; Górecka, M.; Devireddy, A.R.; Karpiński, S.; Mittler, R. ROS, Calcium, and Electric Signals: Key Mediators of Rapid Systemic Signaling in Plants. Plant Physiol. 2016, 171, 1606-1615. [CrossRef]

28. Tabata, R.; Sumida, K.; Yoshii, T.; Ohyama, K.; Shinohara, H.; Matsubayashi, Y. Perception of root-derived peptides by shoot LRR-RKs mediates systemic N-demand signaling. Science 2014, 346, 343-346. [CrossRef]

29. Thieme, C.J.; Rojas-Triana, M.; Stecyk, E.; Schudoma, C.; Zhang, W.; Yang, L.; Miñambres, M.; Walther, D.; Schulze, W.X.; Paz-Ares, J.; et al. Endogenous Arabidopsis messenger RNAs transported to distant tissues. Nat. Plants 2015, 1, 15025. [CrossRef]

30. Yang, B.; Tang, J.; Yu, Z.; Khare, T.; Srivastav, A.; Datir, S.; Kumar, V. Light Stress Responses and Prospects for Engineering Light Stress Tolerance in Crop Plants. J. Plant Growth Regul. 2019. [CrossRef]

31. Chung, P.J.; Park, B.S.; Wang, H.; Liu, J.; Jang, I.-C.; Chua, N.-H. Light-Inducible MiR163 Targets PXMT1 Transcripts to Promote Seed Germination and Primary Root Elongation in Arabidopsis. Plant Physiol. 2016, 170, 1772-1782. [CrossRef]

32. Petrillo, E.; Herz, M.A.G.; Fuchs, A.; Reifer, D.; Fuller, J.; Yanovsky, M.J.; Simpson, C.; Brown, J.W.S.; Barta, A.; Kalyna, M.; et al. A chloroplast retrograde signal regulates nuclear alternative splicing. Science 2014, 344, 427-430. [CrossRef]

33. Ruckle, M.E.; Burgoon, L.D.; Lawrence, L.A.; Sinkler, C.A.; Larkin, R.M. Plastids are major regulators of light signaling in Arabidopsis. Plant Physiol. 2012, 159, 366-390. [CrossRef]

34. Karpinski, S.; Reynolds, H.; Karpinska, B.; Wingsle, G.; Creissen, G.; Mullineaux, P. Systemic signaling and acclimation in response to excess excitation energy in Arabidopsis. Science 1999, 284, 654-657. [CrossRef]

35. Szechyńska-Hebda, M.; Kruk, J.; Górecka, M.; Karpińska, B.; Karpiński, S. Evidence for Light Wavelength-Specific Photoelectrophysiological Signaling and Memory of Excess Light Episodes in Arabidopsis. Plant Cell 2010, 22, 2201-2218. [CrossRef]

36. Asada, K. Production and Scavenging of Reactive Oxygen Species in Chloroplasts and Their Functions. Plant Physiol. 2006, 141, 391-396. [CrossRef]

37. Estavillo, G.M.; Crisp, P.A.; Pornsiriwong, W.; Wirtz, M.; Collinge, D.; Carrie, C.; Giraud, E.; Whelan, J.; David, P.; Javot, H.; et al. Evidence for a SAL1-PAP Chloroplast Retrograde Pathway That Functions in Drought and High Light Signaling in Arabidopsis. Plant Cell 2011, 23, 3992-4012. [CrossRef]

38. Gordon, M.J.; Carmody, M.E.; Albrecht, V.; Pogson, B. Systemic and Local Responses to Repeated HL Stress-Induced Retrograde Signaling in Arabidopsis. Front. Plant Sci. 2013, 3, 303. [CrossRef]

39. Karpinski, S.; Escobar, C.; Karpinska, B.; Creissen, G.; Mullineaux, P.M. Photosynthetic electron transport regulates the expression of cytosolic ascorbate peroxidase genes in Arabidopsis during excess light stress. Plant Cell 1997, 9, 627-640.

40. Ramel, F.; Birtic, S.; Ginies, C.; Soubigou-Taconnat, L.; Triantaphylidès, C.; Havaux, M. Carotenoid oxidation products are stress signals that mediate gene responses to singlet oxygen in plants. Proc. Natl. Acad. Sci. USA 2012, 109, 5535-5540. [CrossRef] 
41. Shao, N.; Duan, G.Y.; Bock, R. A mediator of singlet oxygen responses in Chlamydomonas reinhardtii and Arabidopsis identified by a luciferase-based genetic screen in algal cells. Plant Cell 2013, 25, 4209-4226. [CrossRef] [PubMed]

42. Shumbe, L.; D'Alessandro, S.; Shao, N.; Chevalier, A.; Ksas, B.; Bock, R.; Havaux, M. METHYLENE BLUE SENSITIVITY 1 (MBS1) is required for acclimation of Arabidopsis to singlet oxygen and acts downstream of $\beta$-cyclocitral. Plant Cell Environ. 2017, 40, 216-226. [CrossRef] [PubMed]

43. Wagner, D.; Przybyla, D.; Op den Camp, R.; Kim, C.; Landgraf, F.; Lee, K.P.; Würsch, M.; Laloi, C.; Nater, M.; Hideg, E.; et al. The genetic basis of singlet oxygen-induced stress responses of Arabidopsis thaliana. Science 2004, 306, 1183-1185. [CrossRef] [PubMed]

44. Mühlenbock, P.; Szechyńska-Hebda, M.; Płaszczyca, M.; Baudo, M.; Mateo, A.; Mullineaux, P.M.; Parker, J.E.; Karpińska, B.; Karpiński, S. Chloroplast Signaling and LESION SIMULATING DISEASE1 Regulate Crosstalk between Light Acclimation and Immunity in Arabidopsis. Plant Cell 2008, 20, 2339-2356. [CrossRef]

45. Mullineaux, P.; Ball, L.; Escobar, C.; Karpinska, B.; Creissen, G.; Karpinski, S. Are diverse signalling pathways integrated in the regulation of arabidopsis antioxidant defence gene expression in response to excess excitation energy? Philos. Trans. R. Soc. Lond. B Biol. Sci. 2000, 355, 1531-1540. [CrossRef]

46. Rossel, J.B.; Wilson, P.B.; Hussain, D.; Woo, N.S.; Gordon, M.J.; Mewett, O.P.; Howell, K.A.; Whelan, J.; Kazan, K.; Pogson, B.J. Systemic and Intracellular Responses to Photooxidative Stress in Arabidopsis. Plant Cell 2007, 19, 4091-4110. [CrossRef]

47. Androvic, P.; Valihrach, L.; Elling, J.; Sjoback, R.; Kubista, M. Two-tailed RT-qPCR: A novel method for highly accurate miRNA quantification. Nucleic Acids Res. 2017, 45, e144. [CrossRef]

48. Dai, X.; Zhao, P.X. psRNATarget: A plant small RNA target analysis server. Nucleic Acids Res. 2011, 39, W155-W159. [CrossRef]

49. Finet, C.; Fourquin, C.; Vinauger, M.; Berne-Dedieu, A.; Chambrier, P.; Paindavoine, S.; Scutt, C.P. Parallel structural evolution of auxin response factors in the angiosperms. Plant J. 2010, 63, 952-959. [CrossRef]

50. Hagen, G.; Guilfoyle, T. Auxin-responsive gene expression: Genes, promoters and regulatory factors. Plant Mol. Biol. 2002, 49, 373-385. [CrossRef]

51. Williams, M.E.; Torabinejad, J.; Cohick, E.; Parker, K.; Drake, E.J.; Thompson, J.E.; Hortter, M.; Dewald, D.B. Mutations in the Arabidopsis phosphoinositide phosphatase gene SAC9 lead to overaccumulation of PtdIns(4,5)P2 and constitutive expression of the stress-response pathway. Plant Physiol. 2005, 138, 686-700. [CrossRef] [PubMed]

52. Meurer, J.; Lezhneva, L.; Amann, K.; Gödel, M.; Bezhani, S.; Sherameti, I.; Oelmüller, R. A peptide chain release factor 2 affects the stability of UGA-containing transcripts in Arabidopsis chloroplasts. Plant Cell 2002, 14, 3255-3269. [CrossRef] [PubMed]

53. Stokes, K.D.; McAndrew, R.S.; Figueroa, R.; Vitha, S.; Osteryoung, K.W. Chloroplast Division and Morphology Are Differentially Affected by Overexpression of FtsZ1 and FtsZ2 Genes in Arabidopsis. Plant Physiol. 2000, 124, 1668-1677. [CrossRef] [PubMed]

54. Barczak-Brzyżek, A.K.; Kiełkiewicz, M.; Gawroński, P.; Kot, K.; Filipecki, M.; Karpińska, B. Cross-talk between high light stress and plant defence to the two-spotted spider mite in Arabidopsis thaliana. Exp. Appl. Acarol. 2017, 73, 177-189. [CrossRef] [PubMed]

55. Waszczak, C.; Kerchev, P.I.; Mühlenbock, P.; Hoeberichts, F.A.; Van Der Kelen, K.; Mhamdi, A.; Willems, P.; Denecker, J.; Kumpf, R.P.; Noctor, G.; et al. SHORT-ROOT Deficiency Alleviates the Cell Death Phenotype of the Arabidopsis catalase2 Mutant under Photorespiration-Promoting Conditions. Plant Cell 2016, 28, 1844-1859. [CrossRef] [PubMed]

56. Matsuo, M.; Johnson, J.M.; Hieno, A.; Tokizawa, M.; Nomoto, M.; Tada, Y.; Godfrey, R.; Obokata, J.; Sherameti, I.; Yamamoto, Y.Y.; et al. High REDOX RESPONSIVE TRANSCRIPTION FACTOR1 Levels Result in Accumulation of Reactive Oxygen Species in Arabidopsis thaliana Shoots and Roots. Mol. Plant 2015, 8, 1253-1273. [CrossRef] [PubMed]

57. Hutin, C.; Nussaume, L.; Moise, N.; Moya, I.; Kloppstech, K.; Havaux, M. Early light-induced proteins protect Arabidopsis from photooxidative stress. Proc. Natl. Acad. Sci. USA 2003, 100, 4921-4926. [CrossRef]

58. Auge, G.A.; Perelman, S.; Crocco, C.D.; Sánchez, R.A.; Botto, J.F. Gene expression analysis of light-modulated germination in tomato seeds. New Phytol. 2009, 183, 301-314. [CrossRef]

59. Rizza, A.; Boccaccini, A.; Lopez-Vidriero, I.; Costantino, P.; Vittorioso, P. Inactivation of the ELIP1 and ELIP2 genes affects Arabidopsis seed germination. New Phytol. 2011, 190, 896-905. [CrossRef] 
60. Khan, A.; Goswami, K.; Sopory, S.K.; Sanan-Mishra, N. "Mirador" on the potential role of miRNAs in synergy of light and heat networks. Indian J. Plant Physiol. 2017, 22, 587-607. [CrossRef]

61. Hernando, C.E.; Garcia, C.; Mateos, J.L. Casting Away the Shadows: Elucidating the Role of Light-mediated Posttranscriptional Control in Plants. Photochem. Photobiol. 2017, 93, 656-665. [CrossRef] [PubMed]

62. Wu, H.-P.; Su, Y.-S.; Chen, H.-C.; Chen, Y.-R.; Wu, C.-C.; Lin, W.-D.; Tu, S.-L. Genome-wide analysis of light-regulated alternative splicing mediated by photoreceptors in Physcomitrella patens. Genome Biol. 2014, 15, R10. [CrossRef] [PubMed]

63. Achkar, N.P.; Cho, S.K.; Poulsen, C.; Arce, A.L.; Re, D.A.; Giudicatti, A.J.; Karayekov, E.; Ryu, M.Y.; Choi, S.W.; Harholt, J.; et al. A Quick HYL1-Dependent Reactivation of MicroRNA Production Is Required for a Proper Developmental Response after Extended Periods of Light Deprivation. Dev. Cell 2018, 46, 236-247.e6. [CrossRef] [PubMed]

64. Rogers, K.; Chen, X. Biogenesis, turnover, and mode of action of plant microRNAs. Plant Cell 2013, 25, 2383-2399. [CrossRef] [PubMed]

65. Sunkar, R.; Kapoor, A.; Zhu, J.-K. Posttranscriptional induction of two Cu/Zn superoxide dismutase genes in Arabidopsis is mediated by downregulation of miR398 and important for oxidative stress tolerance. Plant Cell 2006, 18, 2051-2065. [CrossRef]

66. Wang, J.-W.; Wang, L.-J.; Mao, Y.-B.; Cai, W.-J.; Xue, H.-W.; Chen, X.-Y. Control of root cap formation by MicroRNA-targeted auxin response factors in Arabidopsis. Plant Cell 2005, 17, 2204-2216. [CrossRef]

67. Gutierrez, L.; Mongelard, G.; Floková, K.; Pacurar, D.I.; Novák, O.; Staswick, P.; Kowalczyk, M.; Pacurar, M.; Demailly, H.; Geiss, G.; et al. Auxin controls Arabidopsis adventitious root initiation by regulating jasmonic acid homeostasis. Plant Cell 2012, 24, 2515-2527. [CrossRef]

68. Schuman, M.C.; Meldau, S.; Gaquerel, E.; Diezel, C.; McGale, E.; Greenfield, S.; Baldwin, I.T. The Active Jasmonate JA-Ile Regulates a Specific Subset of Plant Jasmonate-Mediated Resistance to Herbivores in Nature. Front. Plant Sci. 2018, 9, 787. [CrossRef]

69. Gläßer, C.; Haberer, G.; Finkemeier, I.; Pfannschmidt, T.; Kleine, T.; Leister, D.; Dietz, K.-J.; Häusler, R.E.; Grimm, B.; Mayer, K.F.X. Meta-analysis of retrograde signaling in Arabidopsis thaliana reveals a core module of genes embedded in complex cellular signaling networks. Mol. Plant 2014, 7, 1167-1190. [CrossRef]

70. Barczak-Brzyżek, A.; Kiełkiewicz, M.; Górecka, M.; Kot, K.; Karpińska, B.; Filipecki, M. Abscisic Acid Insensitive 4 transcription factor is an important player in the response of Arabidopsis thaliana to two-spotted spider mite (Tetranychus urticae) feeding. Exp. Appl. Acarol. 2017, 73, 317-326. [CrossRef]

71. Itoh, R.D.; Fujiwara, M.T. Regulation of leucoplast morphology in roots. Plant Signal. Behav. 2010, 5, 856-859. [CrossRef] [PubMed]

72. Fang, X.; Zhao, G.; Zhang, S.; Li, Y.; Gu, H.; Li, Y.; Zhao, Q.; Qi, Y. Chloroplast-to-Nucleus Signaling Regulates MicroRNA Biogenesis in Arabidopsis. Dev. Cell 2019, 48, 371-382.e4. [CrossRef] [PubMed]

73. Pant, B.D.; Buhtz, A.; Kehr, J.; Scheible, W.-R. MicroRNA399 is a long-distance signal for the regulation of plant phosphate homeostasis. Plant J. 2008, 53, 731-738. [CrossRef] [PubMed]

74. Lindsey, B.E.; Rivero, L.; Calhoun, C.S.; Grotewold, E.; Brkljacic, J. Standardized Method for High-throughput Sterilization of Arabidopsis Seeds. J. Vis. Exp. JoVE 2017, 128, e56587. [CrossRef]

75. Conn, S.J.; Hocking, B.; Dayod, M.; Xu, B.; Athman, A.; Henderson, S.; Aukett, L.; Conn, V.; Shearer, M.K.; Fuentes, S.; et al. Protocol: Optimising hydroponic growth systems for nutritional and physiological analysis of Arabidopsis thaliana and other plants. Plant Methods 2013, 9, 4. [CrossRef]

(C) 2019 by the authors. Licensee MDPI, Basel, Switzerland. This article is an open access article distributed under the terms and conditions of the Creative Commons Attribution (CC BY) license (http://creativecommons.org/licenses/by/4.0/). 